\title{
Identification of novel nitroreductases from Bacillus cereus and their interaction with the CB1954 prodrug
}

Paramasivan, P.; Halliwell, J.H.; Gwenin, V.V.; Poornima, P.; Halliwell, J.; Ball, P.; Robinson, G.; Gwenin, C.D.

\section{Biochemical Pharmacology}

DOI:

10.1016/j.bcp.2015.09.013

Published: 28/09/2015

Peer reviewed version

Cyswllt i'r cyhoeddiad / Link to publication

Dyfyniad o'r fersiwn a gyhoeddwyd / Citation for published version (APA):

Paramasivan, P., Halliwell, J. H., Gwenin, V. V., Poornima, P., Halliwell, J., Ball, P., Robinson, G., \& Gwenin, C. D. (2015). Identification of novel nitroreductases from Bacillus cereus and their interaction with the CB1954 prodrug. Biochemical Pharmacology, 98(3), 392-402.

https://doi.org/10.1016/j.bcp.2015.09.013

\footnotetext{
Hawliau Cyffredinol / General rights

Copyright and moral rights for the publications made accessible in the public portal are retained by the authors and/or other copyright owners and it is a condition of accessing publications that users recognise and abide by the legal requirements associated with these rights. study or research

- Users may download and print one copy of any publication from the public portal for the purpose of private

- You may not further distribute the material or use it for any profit-making activity or commercial gain

- You may freely distribute the URL identifying the publication in the public portal?
}

Take down policy

If you believe that this document breaches copyright please contact us providing details, and we will remove access to the work immediately and investigate your claim. 


\section{Accepted Manuscript}

Title: Identification of novel Nitroreductases from Bacillus cereus and their interaction with the CB1954 prodrug

Author: Vanessa V. Gwenin Paramasivan Poornima Jennifer Halliwell Patrick Ball George Robinson Chris D. Gwenin

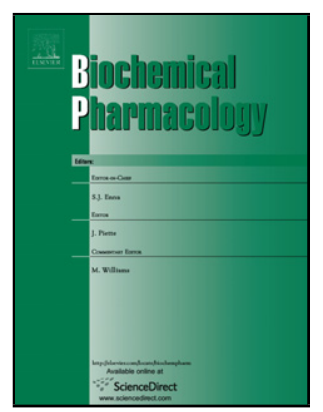

PII:

S0006-2952(15)00623-1

DOI: http://dx.doi.org/doi:10.1016/j.bcp.2015.09.013

Reference: BCP 12382

To appear in: $\quad B C P$

Received date: $\quad 16-7-2015$

Accepted date: $\quad$ 15-9-2015

Please cite this article as: Gwenin Vanessa V, Poornima Paramasivan, Halliwell Jennifer, Ball Patrick, Robinson George, Gwenin Chris D.Identification of novel Nitroreductases from Bacillus cereus and their interaction with the CB1954 prodrug.Biochemical Pharmacology http://dx.doi.org/10.1016/j.bcp.2015.09.013

This is a PDF file of an unedited manuscript that has been accepted for publication. As a service to our customers we are providing this early version of the manuscript. The manuscript will undergo copyediting, typesetting, and review of the resulting proof before it is published in its final form. Please note that during the production process errors may be discovered which could affect the content, and all legal disclaimers that apply to the journal pertain. 


\section{Identification of novel Nitroreductases from}

\section{Bacillus cereus and their interaction with the CB1954}

3 prodrug

5 Robinson ${ }^{1}$, Chris D. Gwenin ${ }^{1 *}$

${ }^{1}$ School of Chemistry, Bangor University, Bangor, Gwynedd, LL57 2DG, Wales, UK

*To whom correspondence should be addressed. Email address: c.d.gwenin@bangor.ac.uk. Tel:

$8+441248383741$.

Running head: Novel nitroreductases from Bacillus cereus that activate the CB1954 prodrug

\section{Graphical abstract}

\section{Abstract}

Directed enzyme prodrug therapy is a form of cancer chemotherapy in which bacterial prodrug-

14 activating enzymes, or their encoding genes, are directed to the tumour before administration of a 
1 prodrug. The prodrug can then be activated into a toxic drug at the tumour site, reducing off-target

2 effects. The bacterial Nitroreductases are a class of enzymes used in this therapeutic approach and

3 although very promising, the low turnover rate of prodrug by the most studied nitroreductase enzyme,

4 NfnB from E. coli (NfnB_Ec), is a major limit to this technology. There is a continual search for enzymes with greater efficiency, and as part of the search for more efficient bacterial nitroreductase enzymes, two novel enzymes from Bacillus cereus (strain ATCC 14579) have been identified and shown to reduce the CB1954 (5-(Aziridin-1-yl)-2,4-dinitrobenzamide) prodrug to its respective 2'-and 4'-hydroxylamine products. Both enzymes shared features characteristic of the Nitro-FMN-reductase Superfamily including non-covalently associated FMN, requirement for the NAD(P)H cofactor,

10 homodimeric, could be inhibited by Dicoumarol (3,3'-methylenebis(4-hydroxy-2H-chromen-2-one),

11 and displayed ping pong bi bi kinetics. Based on the biochemical characteristics and nucleotide

12 alignment with other nitroreductase enzymes, one enzyme was named YdgI_Bc and the other

13 YfkO_Bc. Both B. cereus enzymes had greater turnover for the CB1954 prodrug compared with

14 NfnB_Ec, and in the presence of added NADPH cofactor, YfkO_Bc had superior cell killing ability, 15 and produced mainly the 4'-hydroxylamine product at low prodrug concentration. The YfkO_Bc was 16 identified as a promising candidate for future enzyme prodrug therapy.

\section{Key Words: Bacillus cereus, Nitroreductase, CB1954, prodrug therapy}

\section{Introduction}

Chemotherapy is an important tool in the treatment of cancer and developing drugs or modalities with fewer side effects, but greater efficacy is a necessity. One approach to increase efficacy is to direct the treatment to the tumour, such as in directed enzyme prodrug therapy (DEPT). Bacterial Nitroreductases (NTRs) are a class of enzymes used in this therapeutic approach, and methods to direct these enzymes to solid tumours have included antibodies (ADEPT) [1], viruses (VDEPT) [2], polymers (PDEPT) [3], bacteria (BDEPT) [4], and metal nanoparticles (MNDEPT) [5]. 
The most studied nitroreductase for DEPT is the E. coli NfsB (NfnB_Ec), which can convert the CB1954 prodrug (5-(Aziridin-1-yl)-2,4-dinitrobenzamide) to either the toxic 2'- or 4'-hydroxylamine metabolites, and positive clinical outcomes have been seen for prostate cancer [6], brain tumours [7], as well as for ovarian cancer cell lines [8]. The slow turn-over rate of the CB1954 prodrug (5-(Aziridin-1yl)-2,4-dinitrobenzamide) by NfnB_Ec, however still currently limits the therapeutic efficacy of DEPT [9]. substantial improvements $[10,11,12]$. Other approaches to overcoming the poor turnover of NfnB_Ec for CB1954, have included the identification of other bacterial nitroreductase enzymes [13, 14, 15], or producing CB1954 prodrug derivatives with greater potency, such as PR-104A [16, 17]. hydroxylamine metabolite. The 4'hydroxylamine derivative of CB1954 has been shown to be the more toxic metabolite [21], but has less of a bystander effect compared to the 2'- hydroxylamine [22].

Although oxidoreductases have been isolated from a large number of bacterial species, very few have the required characteristics for DEPT $\{\mathrm{NfnB}$ _Vv (Vibrio vulnificus), YfkO_Bs (Bacillus subtilis) [15], YfkO_Bl (Bacillus licheniformis) [23], a NfnB_Ec (Escherichia coli) mutant [24, 25, 26], and a Frase I_Vf(Vibrio fischeri) mutant [11]\}. No Nitroreductases have been isolated from Bacillus cereus (a 
B. cereus to produce one of the highest levels of reduced fluorogenic nitro-compounds, suggesting the presence of very effective oxidoreductases [29].

For this reason, the B. cereus (ATCC 14579) genome was searched for DNA sequences with high similarity to the $n f n b \_$Ec gene, with the aim of cloning, expressing and characterising the proteins in terms of mechanism, $\mathrm{NAD}(\mathrm{P}) \mathrm{H}$ requirement, flavin content, $\mathrm{pH}$ and temperature stability, reduction of CB1954 prodrug, type of product formation, and ability to induce cell death in SK-OV-3 (Human Caucasian ovary adenocarcinoma cell line). This work set out to identify a promising nitroreductase from B. cereus for DEPT.

\section{Materials and Methods}

All chemicals were obtained from VWR (Lutterworth, UK) unless otherwise stated.

2.1 Cloning of novel proteins. A nucleotide BLAST search of the Bacillus cereus (ATCC 14579) genome was performed using the $n f n B$ gene sequence of Escherichia coli (gene ID: $\underline{945778}$ ). A gene with $33.1 \%$ identity to the $n f n B$ gene was identified as BC_3024 (gene ID: $\underline{\mathbf{1 2 0 5 3 3 7 2}}$ ), possibly encoding a NAD(P)H nitroreductase. Secondly, a putative Oxygen-insensitive NADPH nitroreductase was identified (BC_1619) with gene ID: $\underline{\mathbf{1 2 0 3 9 6 8}}$, and thirdly, a putative nitroreductase family protein with $28.07 \%$ identity was selected (BC_1952, gene ID:1204301). Primers were designed using the free online tools, BioEdit (Ibis biosciences) and NetPrimer (Premier Biosoft International). All restriction enzymes (RE) were obtained from Promega (UK).

To obtain DNA template, B. cereus was grown in nutrient broth $(5 \mathrm{ml})$ overnight and genomic DNA isolated the next day using the Wizard ${ }^{\mathrm{R}}$ Genomic DNA Purification Kit (Promega, UK). PCR was performed using the purified genomic DNA (in ultra-pure water) as template. Phusion High-Fidelity DNA polymerase kit (Thermo Scientific, UK) was used according to the manufacturer's instructions. PCR products were purified using the QIAquick PCR Purification Kit (QIAGEN Ltd, UK) according to the manufacturer's instructions. The purity and approximate size of the PCR products were confirmed 
using agarose gel electrophoresis. Next the pure PCR products were subjected to restriction enzyme (RE) digests using the sites indicated in table 1, whilst the pET28a ${ }^{+}$vector (Novagen, Merck, UK) was separately subjected to the same RE digests including an additional suicide cut using the EcoRI cut site. Digests were also purified using the QIAquick PCR Purification Kit (QIAGEN Ltd, UK) according to the manufacturer's instructions.

Table 1: Primers used for cloning of novel proteins from $B$. cereus

Once purified, ligation between the digested PCR products and $\mathrm{pET} 28 \mathrm{a}^{+}$vector was performed using T4 DNA ligase (New England Biolabs, UK) at $16^{\circ} \mathrm{C}$ overnight. To confirm successful ligation between the gene of interest and the plasmid vector, a PCR based on the T7 promoter and $\mathrm{T} 7$ terminator sequences, which flank the gene insert region contained within the vector, was performed using Taq DNA Polymerase Master Mix (Amplicon, Denmark) according to the manufacturer's instructions. The recombinant plasmids containing the $\mathrm{BC} \_3024, \mathrm{BC} \_1619$, and $\mathrm{BC} \_1952$ genes were renamed pBC3024, $\mathrm{pBC1619}$, and $\mathrm{pBC} 1952$.The plasmids were sequenced on an ABI 3730XL sequencing machine and corresponded to the sequences reported for whole genome sequencing [30]. For amplification of the recombinant plasmids, competent E. coli DH5 $\alpha$ cells $(200 \mu \mathrm{l})$ were transformed with recombinant plasmid $(\sim 10 \mu \mathrm{l})$ and incubated on agar plates containing Kanamycin $(50 \mu \mathrm{g} / \mathrm{ml})$. The Kanamycin antibiotic is used to select for bacterial colonies containing the pET28a $\mathrm{a}^{+}$plasmid with the $18 \quad \mathrm{Kan}^{\mathrm{R}}$ gene.

2.2 Expression of novel proteins. Recombinant plasmids pBC3024, pBC1619, and pBC1952 were transformed into E. coli Rosetta pLysS (Novagen, Merck, UK) competent cells and grown on agar

21 plates containing Kanamycin $(50 \mu \mathrm{g} / \mathrm{ml})$ and $0.5 \%$ glucose. For expression, a single colony was first

22 inoculated into $5 \mathrm{ml}$ of Luria-Bertani (LB) broth/ Kan $(50 \mu \mathrm{g} / \mathrm{ml}) / 0.5 \%$ glucose medium and grown at $2337^{\circ} \mathrm{C}$ overnight. The next day, overnight culture $(5 \mathrm{ml})$ was added to flasks containing LB broth/Kan 24 /glucose $(500 \mathrm{ml})$ and grown up to an $\mathrm{OD}$ of 0.6 at $37^{\circ} \mathrm{C}$ with shaking at $180 \mathrm{rpm}$. Protein expression 25 was induced by adding $2 \mathrm{ml}$ of an IPTG (100 mM, isopropyl- $\beta$-D-thiogalactopyranoside $)$ solution and 
samples grown for a further 4 hours. As a control, IPTG would be omitted from one of the flasks.

Cultures were then spun down at $8000 \mathrm{rpm}(5400 \mathrm{x} \mathrm{g})$ at $4^{\circ} \mathrm{C}$ for $10 \mathrm{~min}$, and pellets were resuspended

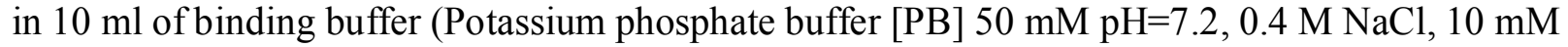
Imidazole), and the supernatant containing the over-expressed proteins purified as previously described [31]. Briefly, over-expressed proteins contain a His-tag for purification using metal ion affinity chromatography using $\mathrm{Ni}_{2}{ }^{+}$, and then eluted with Imidazole. The fractions containing purified protein where then subjected to PD10 columns for exchange chromatography to remove any impurities, mainly Imidazole. When the over-expressed proteins were insoluble, proteins were isolated from the cell debris by resuspending the pellets in a resuspension buffer $(20 \mathrm{ml}, 20 \mathrm{mM}$ Tris-HCL, $0.5 \mathrm{M} \mathrm{NaCl}, \mathrm{pH}=8.0)$, sonicated for $50 \mathrm{sec}$ discontinuously, spun down at $8000 \mathrm{rpm}(5400 \mathrm{x} \mathrm{g})$ at $4^{\circ} \mathrm{C}$ for $10 \mathrm{~min}$, pellets resuspended in isolation buffer $(15 \mathrm{ml}, 20 \mathrm{mM}$ Tris-HCL, $0.5 \mathrm{M} \mathrm{NaCl}, 2 \%$ Triton $\mathrm{X}-100,12 \% \mathrm{w} / \mathrm{v}$ Urea, $\mathrm{pH}=8.0)$, spun down at $9000 \mathrm{rpm}(7000 \mathrm{xg})$ at $4^{\circ} \mathrm{C}$ for $10 \mathrm{~min}$, and the supernatant containing the over-expressed proteins was then purified as described above [31]. The purity and molecular weight of the protein fractions were assessed after separation on a 12\% SDS-PAGE gel during electrophoresis (Mini-PROTEAN Electrophoresis System, Bio-Rad), and visualized with Coomassie blue, before use in further experiments [32]. Protein concentration of purified protein was determined from a BSA standard curve using the ProPure Biuret protein assay (Amresco, NBS Biologicals, UK), according to the manufacturer's instructions. Non-reducing SDS-page was performed as previously described [33].

2.3 Enzyme reactivity to $\mathrm{CB} 1954$ and cofactor requirement. Purified recombinant proteins were tested for reactivity to CB1954 by incubating varying amounts of recombinant protein with NAD(P)H (30 $\mu 1,10 \mathrm{mM}$ stock), CB1954 (10 $\mu 1,10 \mathrm{mM}$ stock), and PB (potassium phosphate buffer $50 \mathrm{mM}, \mathrm{pH}=7.2)$, and measuring absorbance spectra $(600 \mathrm{~nm}-200 \mathrm{~nm})$ every $90 \mathrm{sec}$ for $10 \mathrm{~min}$ on a Jasco V-550, UV/Vis spectrophotometer. Controls were run for prodrug, NAD(P)H, and enzyme as well. All spectra were analysed with the Spectra Manager Software. The specific activity of the purified 
recombinant proteins was calculated using the molar absorptivity of CB1954 hydroxylamine products

2 at $420 \mathrm{~nm}\left(\varepsilon=1200 \mathrm{M}^{-1} \mathrm{~cm}^{-1}\right)[14]$. Michaelis-Menten constants determined.

2.4 Enzyme kinetics. To determine the kinetic parameters of the novel proteins with the CB1954 prodrug, product formation was measured at $420 \mathrm{~nm}$ using the time-drive option on a microplate reader. Purified recombinant proteins $(10 \mu \mathrm{g} / \mathrm{ml})$ were incubated with $\mathrm{NAD}(\mathrm{P}) \mathrm{H}(4 \mathrm{mM})$ in $\mathrm{PB}(50 \mathrm{mM}, \mathrm{pH}=$ 7.2) at $37^{\circ} \mathrm{C}$ for $3 \mathrm{~min}$ prior to adding increasing concentrations of CB1954 (50 $\left.\mu \mathrm{M}-5 \mathrm{mM}\right)$, and measuring initial velocity for a total of $1 \mathrm{~min}$. The DMSO solvent concentration was always kept constant at $5 \% \mathrm{v} / \mathrm{v}$. The amount of product formed per second was calculated using change in absorbance during the first $30 \mathrm{sec}$ and the molar absorptivity of the hydroxylamine products of CB1954 $\left(1200 \mathrm{M}^{-1} \cdot \mathrm{cm}^{-1}\right)$. To determine the enzyme mechanism the enzymes were incubated with a constant CB1954 concentration $(10 \mu \mathrm{M}-150 \mu \mathrm{M})$, whilst varying the $\mathrm{NAD}(\mathrm{P}) \mathrm{H}$ concentrations $(250 \mu \mathrm{M}-5$ $\mathrm{mM}$ ). Hydroxylamine product formation was measured at $420 \mathrm{~nm}$ as mentioned above. To determine whether enzymes possessed flavin reductase activity, a constant concentration of enzyme $(10 \mu \mathrm{g} / \mu \mathrm{l})$ and FMN $(10 \mu \mathrm{M})$ was used, whilst varying the NAD(P)H added $(250 \mu \mathrm{M}-2 \mathrm{mM})$. The amount of FMN reduction was measured at $450 \mathrm{~nm}$ using the molar extinction coefficient of $12500 \mathrm{M}^{-1} \mathrm{~cm}^{-1}$ [34]. Next, nonlinear regression analysis was performed on the rates of product formation $(\mu \mathrm{M} / \mathrm{sec}) v s$ substrate concentrations in SigmaPlot 12 (SPSS, (Systat Software Inc.) and Graphpad Prism 6, and the

2.5 Inhibition kinetics. To determine the inhibition constants, UV-Vis scans were conducted using a 96-well plate on a microplate reader with product formation measured at $420 \mathrm{~nm}$. Each well of the plate contained a constant concentration of CB1954 (5 $\mu 1,40 \mu \mathrm{M}$ and NTR $(10 \mu \mathrm{g} / \mathrm{ml})$, with varying concentrations of NADH $(20 \mu \mathrm{l}, 500 \mu \mathrm{M}-1600 \mu \mathrm{M})$, at different concentrations of Dicoumarol (25 $\mu 1,0 \mu \mathrm{M}-40 \mu \mathrm{M})$. Total volume was made up to $100 \mu 1$ with $\mathrm{PB}(50 \mathrm{mM}, \mathrm{pH} 7.2)$. The plates were incubated for 3 minutes at $37^{\circ} \mathrm{C}$ before enzyme was added and the plates were scanned. The amount of 
product formed per second was calculated using the change of absorbance over 20 seconds and the molar extinction coefficient of the hydroxylamine derivatives at $420 \mathrm{~nm}\left(\varepsilon=1200 \mathrm{M}^{-1} \mathrm{~cm}^{-1}\right)$.

2.6 Temperature and pH profiles of the recombinant enzymes. Purified proteins were incubated with NAD(P)H $(30 \mu 1,10 \mathrm{mM}$ stock $)$, and $\mathrm{PB}(50 \mathrm{mM})$ at increasing temperatures $\left(15^{\circ} \mathrm{C}-80^{\circ} \mathrm{C}\right)$ for 3 min, prior to adding CB1954 (10 $\mu 1,10 \mathrm{mM}$ stock) to the test and DMSO to the reference cell. For the pH stability, purified recombinant proteins were incubated with NAD(P)H (30 $\mu 1,10 \mathrm{mM}$ stock), in a range of phosphate buffers $(\mathrm{pH}=2$ to $\mathrm{pH}=11)$ for $3 \mathrm{~min}$ at $30^{\circ} \mathrm{C}$ before adding $\mathrm{CB} 1954(10 \mu 1,10 \mathrm{mM}$ stock) to the test and DMSO to the reference cell. All absorbance spectra (600 nm - $200 \mathrm{~nm})$ were recorded every $90 \mathrm{sec}$ for $10 \mathrm{~min}$ on a Jasco V-550, UV/Vis spectrophotometer and analysed with the spectra manager software.

2.7 Confirming the presence of FMN. The purified proteins were denatured with heat treatment at $70^{\circ} \mathrm{C}$ for $20 \mathrm{~min}$ to liberate the bound $\mathrm{FMN}$, followed by centrifugation at $10,000 \mathrm{Xg}$ for $20 \mathrm{~min}$ [35]. The supernatant was analysed by thin-layer chromatography (TLC) using a solvent system of $\mathrm{Na}_{2} \mathrm{PO}_{4}$ and the developed plates were visualized under UV light at $366 \mathrm{~nm}$.

2.8 HPLC analysis on reaction products. The following components were added into a $15 \mathrm{ml}$ Falcon tube covered in foil: $120 \mu \mathrm{l}$ NAD(P)H (10 mM), $20 \mu \mathrm{l} \mathrm{CB1954} \mathrm{(50} \mathrm{mM),} \mathrm{enzyme} 116 \mu \mathrm{g} / \mathrm{mL}$ final concentration, and made up to a final volume of $1.080 \mathrm{ml}$ with $50 \mathrm{mM} \mathrm{PB}(\mathrm{pH}=7.2)$. The reaction mixture was incubated at $25^{\circ} \mathrm{C}$ for 30 minutes. Prior to HPLC analysis the reaction mixture was degassed using nitrogen $(\mathrm{g})$ for $10 \mathrm{~min}$. Next, $600 \mu \mathrm{l}$ of the de-gassed mixture was placed into a Chromacol Select $2 \mathrm{~mL}$ vial (2-SVW8-CP) and placed in an Ultimate 3000 UHPLC machine (thermo Scientific) using a reverse phase column. The solvent consisted of an acetonitrile/ water mixture, beginning with $10 \%$ acetonitrile and increasing by $1 \%$ per minute. After a 20 minute run this gradient increases to $40 \%$ acetonitrile per minute, reaching $100 \%$ after 22 minutes. Eluents were scanned at 4 different wavelengths $260 \mathrm{~nm}, 300 \mathrm{~nm}, 350 \mathrm{~nm}$, and $420 \mathrm{~nm}$. Product peaks were identified after comparison with all reagents prior to the start of the enzymatic reaction. The ratios of the 4'- 
according to literature [15] and then using absorbance at $420 \mathrm{~nm}$, where both products have equal absorption [36].

2.9 In Vitro Cytotoxicity assays. The MTT assay was performed following the method of Mossman, 1983 with slight modification. [37] Briefly, SK-OV-3 cells (Sigma Aldrich, United Kingdom) were seeded at a density of $1 \mathrm{X} 10^{4}$ cells per well, in $100 \mu$ l Dulbecco's Modified Eagles Medium (DMEM) containing $10 \% \mathrm{FBS}$ and were allowed to attach overnight in $\mathrm{CO}_{2}$ incubator. After 16 hours, medium was carefully flicked off, and $50 \mu \mathrm{l}$ of medium containing CB1954 (20 $\mu \mathrm{M})$ either in the presence or absence of NAD(P)H $(200 \mu \mathrm{M})$ was added. Next, medium containing a set amount of purified enzyme from section $2.2(50 \mu \mathrm{l})$ was added and after $4 \mathrm{~h}$, the medium was removed and cells were replenished with complete DMEM $(100 \mu \mathrm{l})$. After $48 \mathrm{~h}, 20 \mu \mathrm{l}$ of MTT $(5 \mathrm{mg} / \mathrm{ml})$ was added to each well and incubated at $37^{\circ} \mathrm{C}$ for $4 \mathrm{~h}$. The purple formazan crystals formed were dissolved in $100 \mu \mathrm{l}$ of dimethyl sulfoxide after removing the media carefully and the absorbance was read at $570 \mathrm{~nm}$ in a microplate reader.

14

\section{Results}

3.1 Cloning and sequencing. Three Bacillus cereus genes were successfully amplified during PCR and inserted into the pET28a+ expression vector, which inserts an N-terminal Histidine-tag (his-tag) for ease of purification of the proteins. The plasmids containing the three B. cereus genes were sequenced, which confirmed the identity of the genes [30].

3.2 Expression of novel proteins. Preliminary expression experiments of the three B. cereus genes indicated that the addition of $0.5 \%$ glucose was beneficial [38] and incubation temperature of $37^{\circ} \mathrm{C}$ gave good overexpression. The BC_1952 did not express well and was often found to accumulate with the cell debris, suggesting failure of the protein to fold correctly. All protein supernatants were bright yellow in colour when compared to supernatants of un-induced cultures. The yellow coloured solutions were subsequently purified using metal ion affinity chromatography $\left(\mathrm{Ni}^{2+}\right)$ and his-tagged proteins 
eluted with an Imidazole gradient $(10 \mathrm{mM}-500 \mathrm{mM})$. As seen from the denaturing SDS-PAGE in

Figure 1 (Top), the BC_3024 enzyme eluted mainly at a concentration of $300 \mathrm{mM}$ Imidazole (lane 8) as a single band with an approximate molecular weight of $27 \mathrm{kDa}$. The BC_3024 protein under nondenaturing (native) conditions (Figure 1, Bottom) appeared to have a molecular weight between 55 and $72 \mathrm{kDa}$, which is roughly twice the molecular mass seen in the denaturing gel. These results suggested that the protein was most likely a homodimer.

The BC_1619 protein, as seen from the denaturing SDS-PAGE in Figure 2 (Top), eluted between 300

$\mathrm{mM}$ and $500 \mathrm{mM}$ Imidazole (lane 8 and 9) as a single band between 26 and $34 \mathrm{kDa}$. The BC_1619 protein under non-denaturing (native) conditions (Figure 2, Bottom) gave an approximate molecular weight of $60 \mathrm{kDa}$, which is again roughly twice the molecular mass seen in the denaturing gel. These results implied that the BC_1619 was most likely also a homodimer.

The BC_1952 protein was also eluted from the $\mathrm{Ni}^{2+}$ column using $300 \mathrm{mM}$ and $500 \mathrm{mM}$ Imidazole and appeared to migrate as a single band in denaturing PAGE roughly at $26 \mathrm{kDa}$ (data not shown), and in a non-denaturing PAGE at above $55 \mathrm{kDa}$. The results suggested that BC_1952 was multimeric in its native form, but it could not be confirmed what the exact number of subunits or their size were. It is worth noting that the molecular weight of all the expressed recombinant proteins was approximately 3.6

$17 \mathrm{kDa}$ greater than the predicted molecular mass based on the gene sequences alone, due to the presence of the His-Tag added during cloning.

$19 \quad 3.3$ Presence of FMN. The yellow colour of the expressed protein solutions suggested that these proteins were associated with FMN [35]. To prove the association with FMN, TLC analysis was performed of denatured protein solutions and compared with a FMN and FAD standard (Figure 3). After enzyme denaturation, all three expressed enzymes, BC_3024, BC_1619, and BC_1952 appeared to have FMN present, although the FMN from the enzyme migrated slightly lower in TLC than the FMN standard. Furthermore, performing UV-Vis scans on the proteins showed absorption peaks around $460 \mathrm{~nm}$, consistent with the presence of FMN [35]. 
3.4 Enzyme reduction of CB1954 prodrug. It was next determined whether the three enzymes

could reduce the $\mathrm{CB} 1954$ prodrug in presence of $\mathrm{NAD}(\mathrm{P}) \mathrm{H}$ cofactors. Prior to purification, crude extracts of BC_1952, BC_3024 and BC_1619 were assessed for their ability to reduce the CB1954 prodrug in the presence of excess $\mathrm{NAD}(\mathrm{P}) \mathrm{H}$. Full wavelength scans $(200 \mathrm{~nm}-600 \mathrm{~nm})$ were obtained every minute for 10 minutes. Product formation was recorded at $420 \mathrm{~nm}$. The BC 1952 enzyme showed little to no activity to the prodrug using either of the cofactors. Both BC_3024 and BC_1619 cell extracts showed reductase activity. Purified BC_3024 reduced the prodrug to products which absorbed at $420 \mathrm{~nm}$ using either NADH or NADPH as cofactor. The BC_1619 enzyme could also reduce the CB9154 prodrug, using either NADH or NADPH, but had preference for the NADPH cofactor. In the absence of either enzyme, cofactor or prodrug, no nitro-reduction occurred. The BC_1952 enzyme was additionally tested with TNT and dinitrobenzamide, but did not show significant activity and BC_1952 was abandoned at this point and no further experiments performed, but may require further characterisation in the future.

3.5 Temperature and pH profiles. Prior to determining the kinetics of the two active B. cereus enzymes, the temperature and $\mathrm{pH}$ profiles were determined. The BC_3024 enzyme reduced CB1954 prodrug at a broad range of temperatures; the optimum being between $30-40^{\circ} \mathrm{C}$ (data not shown). Enzyme activity decreased significantly above $50^{\circ} \mathrm{C}$, and the enzyme was stable at pH 5 to 9 ; the optimum at $\mathrm{pH}=7$ (data not shown). The BC_1619 enzyme reduced prodrug optimally between 30 and $40^{\circ} \mathrm{C}$, but lost activity at temperatures above $50^{\circ} \mathrm{C}$. Compared to BC_3024, BC_1619 had a narrower $\mathrm{pH}$ range and the optimum was around $\mathrm{pH}=7.4$ (data not shown).

3.6 Enzyme kinetics. The kinetic parameters of the two novel enzymes for CB1954 were determined using the absorbance of the hydroxylamine products measured at $420 \mathrm{~nm}$ in UV-Vis spectroscopy and data was analysed using SigmaPlot 12 and Graphpad Prism 6. Results are summarised in Table 2. s seen in Table 2, the BC_3024 enzyme had a turnover for CB1954 $\left(45 \mathrm{~s}^{-1}\right)$ using NADPH, which is greater than that of NfnB_Ec $\left(25 \mathrm{~s}^{-1}\right)$ [14]. The novel enzyme also had a lower $\mathrm{K}_{\mathrm{m}}(2700 \mu \mathrm{M}$ compared to $4060 \mu \mathrm{M}$ for $\mathrm{NfnB})$, and greater efficiency $\left(16,760 \mathrm{M}^{-1} \mathrm{~s}^{-1}\right.$ compared to $6180 \mathrm{M}^{-1} \mathrm{~s}^{-1}$ for $\mathrm{NfnB}$, Table 
2). The BC_3024 enzyme could use both NADH and NADPH as cofactor, and based on turnover, showed slight preference for NADH, The enzyme had limited FMN reductase activity.

The kinetic analysis for BC_1619 (Table 2) gave a turnover of $60 \mathrm{~s}^{-1} 1$ for CB1954, and a $\mathrm{K}_{\mathrm{m}}$ of $2800 \mu \mathrm{M}$. However, BC_1619 used NADPH as the preferred cofactor based on the turnover, and had greater FMN reduction, compared to BC_3024.

3.7 Analysis of reaction products. Using NfnB_Ec as a model enzyme, CB1954 reduction products were identified in HPLC initially using absorbance at 260nm [15], and corresponding this with the absorbance at $420 \mathrm{~nm}$ for validation of a new approach. As seen from Figure 4, Both the 4'hydroxylamine (4.8-5.5 $\mathrm{min})$ and 2'-hydroxylamine (9.5 -11.4 $\mathrm{min}$ ) products were detected at $420 \mathrm{~nm}$ as well as the presumed amino derivates ( after $15 \mathrm{~min}$ ). By directly comparing the areas under the curves for the two product peaks at $420 \mathrm{~nm}$ [36], the ratio of 4'-hydroxylamine vs 2'-hydroxylamine was determined to be 49: 51. This correlated very well with what has previously been described for NfnB_Ec using absorbance at 260nm and separate molar extinction coefficients [15]. Applying the $420 \mathrm{~nm}$ analysis of NfnB products to the HPLC chromatogram for BC_3024 (Figure 5), the CB1954 reduction products were identified, and it was determined that the 2'hydroxylamine (9.5-11.5 $\mathrm{min}$ ) was major product. The 4'hydroxylamine (5 min) was the minor product. It was determined that the ratio of 4'-hydroxylamine vs 2'-hydroxylamine was 14: 86 produced by BC_3024 (Figure 5). An additional two products were also detected downstream of the hydroxylamines, and these were thought to be the 4'-amino and 2'-amino derivatives, which are either end products of enzyme catalysis, or non-enzymatic rearrangements [39]. To the contrary, the BC_1619 enzyme produced more of the 4'-hydroxylamine product in a ratio of 67: 33 (4' vs 2'-hydroxylamine) (Figure 6).

3.8 Inhibition kinetics. The Dixon plot and double reciprocal plots were used as an initial indications of the type of inhibition that Dicoumarol may have on NADH binding to the novel enzymes [40].The Dixon plot for BC_3024 (Figure 7) suggested uncompetitive inhibition, but the double reciprocal plot (data not shown) suggested competitive inhibition. Taken together, these graphical 
results would suggest a case of mixed inhibition. Simultaneous nonlinear regression (SNLR) has been shown to be more accurate for determining inhibition types and kinetic parameters compared with graphical methods and kinetic parameters for BC_3024 were determined using Graphpad Prism version 6 (Table 3) [41]

Using the mixed inhibition model in Graphpad, which compares competitive, non-competitive and uncompetitive models, it was shown that the data for BC_3024 was best described with the uncompetitive inhibition model in which the $0<\alpha<1$. This was achieved using a $95 \%$ confidence interval and all curves had $\mathrm{R}$ square values of $0.91-0.99$. Both the $\mathrm{V}_{\max }$ and $\mathrm{K}_{\mathrm{m}}$ for NADH were decreased by the presence of Dicoumarol (Table 3) providing support for an uncompetitive inhibition type. However, according to literature [42], it is very rare for the inhibitor to only bind to the enzyme-

11 substrate complex and is more a case of preference, in which the affinity of Dicoumarol for enzyme-

12 substrate complex is greater than affinity for enzyme alone. Under the conditions tested here, the

13 Dicoumarol inhibitor preferentially bound to the BC_3024 enzyme-substrate complex, such that the

14 association constants were estimated to be $\mathrm{K}_{\mathrm{i}}[\mathrm{ES}]=23 \mu \mathrm{M}$ and $\mathrm{K}_{\mathrm{i}}[\mathrm{E}]=70 \mu \mathrm{M}$. Uncompetitive inhibition of NADH by Dicoumarol has however not been reported for other nitroreductases.

The Dixon plot (Figure 8) for the BC_1619 enzyme suggested that the binding of NADPH was competitively inhibited by Dicoumarol, as for most nitroreductases reported in literature. To confirm this and determine the kinetic parameters, SNLR was performed using Graphpad Prism 6, which

19 showed $\mathrm{K}_{\mathrm{m}}$ to increase slightly in presence of inhibitor (Table 3), while $\mathrm{V}_{\max }$ remained constant. The 20 inhibition constant $\left(\mathrm{K}_{\mathrm{i}}[\mathrm{E}]\right)$ was determined to be $2095 \mu \mathrm{M}$.

The SNLR results for BC_1619 confirmed competitive inhibition, in which the inhibitor competes for binding to the same form of the enzyme as the substrate and at high enough substrate concentrations, $\mathrm{V}_{\max }$ can still be achieved. 
Firstly, it has been shown here that the BC_3024 enzyme converts CB1954 into either the 4'-

2 hydroxylamine or the 2'-hydroxylamine products using NADH/ or NADPH as electron donor. Thus, there are two substrates $(\mathrm{CB} 1954$ and $\mathrm{NAD}(\mathrm{P}) \mathrm{H})$ and two products (a hydroxylamine/ or amino and $\mathrm{NAD}(\mathrm{P})+)$, which makes it a bi bi reaction. Furthermore, the parallel lines obtained in the double reciprocal plots of 1/u vs 1/[NADH] (Figure 9, A) and 1/v vs 1/[CB1954] (Figure 9, C), indicated that the enzyme follows an ping pong bi bi mechanism, which means that the first product needs to dissociate from the enzyme, before the second substrate will bind [42].

Similarly, the BC_1619 consists of a two substrate and two product reaction (bi bi) and also produced parallel lines in the double reciprocal plots for $1 / \mathrm{v}$ vs $1 /[\mathrm{NADH}]$ (Figure 9, B) and 1/v vs $1 /[\mathrm{CB} 1954]$ (Figure 9, D), which is characteristic of a ping pong bi bi mechanism [42].

3.10 Cell toxicity studies. Percentage cell survival of SK-OV-3 cells was determined in presence of increasing enzyme concentration, a constant concentration of prodrug $(10 \mu \mathrm{M})$, and the presence or absence of added NAD(P)H cofactor. As controls, cells were incubated with medium only, enzyme only, or prodrug only (Figure 10).

As seen from Figure 10, no significant cell death was caused by the combination of BC_3024 and CB1954 in absence of added cofactor. In the presence of added NADH, percentage cell kill was 26\%, but this enzyme could not improve on the cell killing of NfnB_Ec, which achieved up to $40 \%$ cell killing (data not shown). Greater cell killing of BC_3024 was observed in the presence of increasing CB1954 concentrations (data not shown), but this would not be of benefit clinically.

To the contrary, the BC_1619 enzyme and CB1954 in the presence of NADPH induced a significant decrease in cell survival (60\%, Figure 11), similar to that seen for NfsA_Ec [15]. In absence of added cofactor however, BC_1619 and CB1954 could not cause significant cell killing (Figure 11). Also seen from Figure 11, there is a decrease in cell killing at higher concentrations of BC_1619 enzyme, which appears to be contradictory. However, this phenomenon has been well described in literature and is 
known as the Hormetic effect [44], in which the dose-response curve shows cell sensitivity at low concentrations, but not at higher concentrations of agent. Also seen from both Figures 10 and 11, was that neither the enzymes nor the cofactor alone could cause significant cell death.

\section{Discussion}

The major aim of this research was to identify, clone and express novel proteins from B. cereus which had features similar to that of the E.coli $\mathrm{NfnB}$ protein and assess their ability to reduce the CB1954 prodrug and cause cell death in a cancer cell line. It was hoped that at least one of the novel proteins would be a suitable candidate for use in our novel enzyme prodrug therapy (MNDEPT) [5]. All the aims were achieved and three $B$. cereus proteins were successfully cloned, expressed and purified, and all of those were tightly associated with FMN (Figure 3) and appeared to be homodimers, just like NfnB_Ec [45]. One of the proteins (BC_1952) though, was not active with prodrug or any other compound (TNT and Dinitrobenzamide, data not shown) using either NADH or NADPH. Due to the difficulty in purifying this enzyme, it was hypothesised that poor activity was due to misfolding or instability. For the purpose of this work, the BC_1952 protein was not further investigated, but attention shifted to the BC_1619 and BC_3024 proteins. Both of the last mentioned proteins had superior enzyme kinetics to the CB1954 prodrug compared with native NfnB_Ec (Table 2) [13]. The BC_1619 enzyme preferred NADPH and was competitively inhibited by dicoumarol (Figure 7), similarly to the nitroreductase from Enterobacter cloacea [Error! Bookmark not defined.]. The Dixon plot for inhibition of the BC_3024 enzyme showed that NADH binding was both competitively and uncompetitively inhibited, suggesting mixed inhibition (Figure 7). However, SNLR indicated that the data was best fit using the uncompetitive inhibition model, which is different from any nitroreductase reported to date. A possible explanation for the differences seen here for the BC_3024 enzyme could be explained based on crystal structure analysis of the most studied nitroreductase (NfnB_Ec) [46]. It has been shown with NfnB_Ec, that there are two channels in the protein which lead to the active site. For NfnB_Ec, NADH and CB1954 prefer the A-channel because 
available space, but the B-channel is blocked by a Phe124 residue. Thus for NfnB, there appears really only one option for Dicoumarol, and that is to compete with the NADH for binding to the A-channel.

However, it could be that BC_3024 has a slightly different active site conformation in which both A- and B- channels are open for substrate binding. A possible explanation for the uncompetitive inhibition seen here, is that the larger NADH has a preference for the A-channel, leaving Dicoumarol to bind preferentially to the smaller B-channel. Thus, this would result in Dicoumarol binding to the enzyme-NADH complex and causing uncompetitive inhibition. Computational modelling and crystallisation was however not in the scope of this research and may be worth investigating in the future.

As part of the enzyme characterisation, double reciprocal plots of initial velocities (Figure 9) were used to determine enzyme mechanism [Error! Bookmark not defined.]. It was shown that both the BC_1619 and BC_3024 enzymes followed a ping pong bi bi reaction mechanism. Taken together, the two novel proteins from $B$. cereus were classified as oxygen-insensitive nitroreductases, based on the following characteristics: reduce nitro-groups to hydroxylamine derivatives in presence of oxygen; follow a ping pong bi bi mechanism; require NADH or NADPH as cofactors; are homodimers; contain a FMN prosthetic group; and are strongly inhibited by dicoumarol [47, 48, 49].

In order to decide on names that most closely described the two novel proteins, both homology searching and biochemical characterisations were used to rename the B. cereus enzymes. The BC_3024 enzyme shared highest identity (69\%) to the YdgI enzyme from Bacillus subtilis (YdgI_Bs) using the predicted amino acid sequence (DELTA-BLAST, NCBI database). Similarly to the YdgI_Bs, BC_3024 had a preference for NADH and produced more of the 2'-hydroxylamine product compared to the 4'hydroxylamine [13]. It was for this reason that BC_3024 from Bacillus cereus was renamed as YdgI_Bc.

The BC_1619 sequence contains the NfsA_FRP region and was shown to share highest identity with the Nfra1-nitroreductase protein (42\%) from B. subtilis, when searching the NCBI protein database (PDB). Different from its closest relative however (Figure 6), BC_1619 produced more of the 4'- 
hydroxylamine than the 2'-hydroxylamine product upon reduction of CB1954, and had very different kinetic parameters. When comparing evolutionary relatedness, it was noted that BC_1619 was distantly related to YfkO_Bs (Figure 12), with which it shares most, if not all biochemical similarities. YfkO_Bs produces CB1954 hydroxylamine reduction products in a ratio of 75: 25 (4' vs 2'), whilst BC_1619 produces them in a ratio of $67: 33$. Furthermore, YfkO_Bs also prefers NADPH as cofactor and produces CB1954 kinetic parameters almost identical to that of BC_1619 [13]. It was thus decided to rename BC_1619 as YfkO_Bc [NAD(P)H Nitroreductase from Bacillus cereus].

Apart from characterising new proteins from B. cereus, this article also describes a new approach to determining the identity and amount of CB1954 reduction products using HPLC. To date, literature has used the absorbance at $260 \mathrm{~nm}$ to determine the amount and the ratio of each hydroxylamine product during HPLC analysis using the individual molar absorptivity constants for each product [15]. It is however known that both CB1954 hydroxylamine products have the same molar absorptivity at $420 \mathrm{~nm}$ [15], and that at this wavelength the greatest distinction between the 2'-and 4'-hydroxylamine peaks was seen. Using the solvent system described here, it was found that the 4'- hydroxylamine eluted around 5 min, whereas the 2'-hydroxylamine eluted between 9.5-11.4 min (Figure 5 and 6). To determine molar ratio of products produced, areas under the identified curves were directly compared.

17 Our method was verified by comparing HPLC data for $\mathrm{NfnB}$ Ec (Figure 4) and $\mathrm{YfkO}$ _B. licheniformis 18 (data not shown) with results from literature [50, 23].

19 Finally, to determine whether a new enzyme has promise for use in DEPT using the CB1954 prodrug, it needs to have some basic characteristics, such as a high turnover for prodrug at low substrate concentrations, and the production of the more toxic 4 'hydroxylamine metabolite. It is worth noting that although the 4'hydroxylamine derivative of CB1954 is more toxic [51], it has less of a

23 bystander effect compared to the 2'-hydroxylamine [52].

Both the novel enzymes assessed here (YdgI_Bc and YfkO_Bc), had the above mentioned characteristics (Table 2, Figure 5 and 6). However, in 2D cell culture YdgI_Bc was not very effective at inducing SK-OV-3 cell death in the presence of CB1954 prodrug either in absence or presence of added 
1 NADH cofactor (Figure 10). The YfkO_Bc however, was much more effective at inducing SK-OV-3

2 cell death in the presence of added cofactor (Figure 11), compared with native NfnB_Ec (data not

3 shown). These results confirmed that $\mathrm{YfkO}_{-} \mathrm{Bc}$ was a promising candidate for DEPT.

4 In conclusion, two novel enzymes from B. cereus have been isolated, characterised and re-named.

5 Also a modified HPLC method for determination of CB1954 reduction products has been described and

6 kinetic parameters were determined using the latest methodology (SNLR). Furthermore, the YfkO_Bc

7 has been shown to be an excellent candidate for DEPT in that it has a high turnover for CB1954 at low

8 substrate concentrations, produces mainly the 4'hydroxylamine product, is active at physiological $\mathrm{pH}$,

9 and induces significant SK-OV-3 cancer cell death in presence of NADPH. It is envisaged, that once

10 the YfkO_Bc enzyme is immobilised onto gold-coated magnetic nanoparticles and directed to the

11 cytoplasm of targeted cells (MNDEPT), this enzyme-prodrug combination will surpass the currently

12 investigated DEPT approaches.

13 Acknowledgement. The authors thank the School of Chemistry at Bangor University for their

14 support throughout this project, as well as funding from Welsh Government and the Life Sciences

15 Research Network Wales. The authors would also like to acknowledge Miss Ellen Freeborn for a

16 contribution to some of the enzyme kinetics experiments.

\section{References}

[1] Bagshawe KD. Antibody-Directed Enzyme Prodrug Therapy. In: Prodrugs, edited by Stella VJ, Borchardt RT, Hageman MJ, Oliyai R, Maag H and Tilley JW. New York: Springer New York, 2007, p. 527-528.

[2] Knox RJ, Burke PJ, Chen S, and Kerr DJ. CB1954: From the walker tumor to NQ02 and

VDEPT. Curr Pharm Design 2006: 9: 2091-2104. 
[3] Duncan R, Gac-Breton S, Keane R, Musila R, Sat YN, Satchi R, and Searle F. Polymer-drug conjugates, PDEPT and PELT: basic principles for design and transfer from the laboratory to clinic. J Control Release 2001: 74: 135-146.

[4] Heap J, Theys J, and Minton NP. Spores of Clostridium engineered for clinical efficacy and safety cause regression and cure of tumors in vivo. Oncotarget 2014: 5: 1761-9.

[5] Gwenin VV, Gwenin CD, and Kalaji M. Colloidal gold modified with a genetically Engineered nitroreductase: toward a novel enzyme delivery system for cancer prodrug therapy. Langmuir 2011:27: 14300-7.

[6] Patel P, Young JG, Mautner V, Ashdown D, Bonney S, Pineda RG, et al. A Phase I/II clinical trial in localized prostate cancer of an adenovirus expressing nitroreductase with CB1954. Mol Ther 2009: 17: 1292-9.

[7] Drabek D, Guy J, Craig R, and Grosveld F. The expression of bacterial nitroreductase in transgenic mice results in specific cell killing by the prodrug CB1954. Gene Ther 1997: 4: 93-100.

[8] Weedon SJ, Green NK, Mcneish IA, Gilligan MG, Mautner V, Wrighton CJ, Mountain A, Young LS, Kerr DJ, and Searle PF. Sensitisation of Human carcinoma cells to the prodrug CB1954 by adenovirus vector-mediated expression of E.coli nitroreductase. Int J Cancer 2000: 86: 848-854.

[9] Searle PF, Chen M-J, Hu L, Race PR, Lovering AL, Grove JI, et al. Nitroreductase: A prodrugactivating enzyme for cancer gene therapy. Clin Exp Pharmacol 2004: 31: 811-6.

[10] Anlezark GM, Melton RG, Sherwood RF, Coles B, Friedlos F, and Knox RJ. The bioactivation of 5-(aziridin-1-yl)-2,4-dinitrobenzamide (CB 1954)-I. Purification and properties of a nitroreductase enzyme from Escherichia coli- A potential enzyme for antibody-directed enzyme prodrug therapy (ADEPT). Biochem Pharmacol 1992: 44: 2289-95. 
[11] Swe PM, Copp JN, Green LK, Guise CP, Mowdayb AM, Smaill JB, et al. Targeted mutagenesis of the Vibrio fischeri flavin reductase FRase I to improve activation of the anticancer prodrug CB1954. Biochem Pharmacol 2012: 84: 775-83.

[12] Jarrom D, Jaberipour M, Guise CP, Daff S, White SA, Searle PF and Hyde EI, Steady-State and Stopped-Flow Kinetic Studies of Three Escherichia coli NfsB Mutants with Enhanced Activity for the Prodrug CB1954. Biochem 2009: 48: 7665-72.

[13] Prosser GA, Copp JN, Mowday AM, Guise CP, Syddall SP, Williams EM, et al. Creation and screening of a multi-family bacterial oxidoreductase library to discover novel nitroreductases that efficiently activate the bioreductive prodrugs CB1954 and PR-104A. Biochem Pharmacol 2013: 85: 1091-1103.

[14] Prosser GA, Copp JN, Syddall SP, Williams EM, Smaill JB, Wilson WR, et al. Discovery and evaluation of Escherichia coli nitroreductases that activate the anti-cancer prodrug CB1954. Biochem Pharmacol 2010: 79: 678-87.

[15] Vass S, Jarrom D, Wilson W, Hyde E, and Searle P. E. coli NfsA: an alternative nitroreductase for prodrug activation gene therapy in combination with CB1954. Brit J Cancer 2009: 100: 1903-11.

[16] Jameson MB, Rischin D, Pegram M, Gutheil J, Patterson AV, Denny WA, and Wilson WR. A phase I trial of PR-104, a nitrogen mustard prodrug activated by both hypoxia and aldo-keto reductase 1C3, in patients with solid tumors. Cancer Chemother Pharmacol 2010: 65: 791801.

[17] Guise CP, Abbattista MR, Singleton RS, Holford SD, Connolly J, Dachs GU, et al. The Bioreductive Prodrug PR-104A Is Activated under Aerobic Conditions by Human Aldo-Keto Reductase 1C3. AACR. 2010: 70: 1573-84. 
[18] González-Pérez MM, Dillewijn Pv, Wittich R-M, and Ramos JL. Escherichia coli has multiple enzymes that attack TNT and release nitrogen for growth. Environ Microbiol 2007: 9: 153540.

[19] Hayashi M, Hasegawa K, Oguni Y, and Unemot T. Characterization of FMN-dependent NADH-quinone reductase induced by menadione in Escherichia coli. BBA 1990: 1035: 2306.

[20] Anlezark GM, Vaughan T, Fashola-Stone E, Michael NP, Murdoch H, Sims MA, et al. Bacillus amyloliquefaciens orthologue of Bacillus subtilis ywrO encodes a nitroreductase enzyme which activates the prodrug CB 1954. Microbiol 2002: 148: 297-306.

[21] Helsby NA, Wheeler SJ, Pruijn FB, Palmer BD, Yang S, Denny WA, et al. Effect of Nitroreduction on the Alkylating Reactivity and Cytotoxicity of the 2,4-Dinitrobenzamide-5aziridine CB 1954 and the Corresponding Nitrogen Mustard SN 23862: Distinct Mechanisms of Bioreductive Activation. Chem Res Toxicol 2003: 16: 469-78.

[22] Helsby NA, Ferry DM, Patterson AV, Pullen SM, and Wilson WR. 2-Amino metabolites are key mediators of CB 1954 and SN 23862 bystander effects in nitroreductase GDEPT. Brit J Cancer 2004: 90: 1084-92.

[23] Emptage CD, Knox RJ, Danson MJ, and Hough DW. Nitroreductase from Bacillus licheniformis: A stable enzyme for prodrug activation,. Biochem Pharmacol 2009: 77: 21-9.

[24] Grove JI, Lovering AL, Guise C, Race PR, Wrighton CJ, White SA, et al. Generation of Escherichia Coli Nitroreductase Mutants Conferring Improved Cell Sensitization to the Prodrug CB1954. Cancer Res 2003: 63: 5532-7.

[25] Jaberipour M, Vass SO, Guise CP, Grove JI, Knox RJ, Hu L, et al. Testing double mutants of the enzyme nitroreductase for enhanced cell sensitisation to prodrugs: Effects of combining beneficial single mutations. Biochem Pharmacol 2009: 79: 102-11. 
[26] Jarrom D, Jaberipour M, Guise CP, Daff S, White SA, Searle PF, and Hyde EI. Steady-State and Stopped-Flow Kinetic Studies of Three Escherichia coli NfsB Mutants with Enhanced Activity for the Prodrug CB1954. Biochem 2009: 48: 7665-72.

[27] Drobniewski FA. Bacillus cereus and Related Species. Clin Microbiol Rev 1993: 6: 324-38.

[28] Helgason E, Okstad OA, Caugant DA, Johansen HA, Fouet A, Mock ML, et al. Bacillus anthracis, Bacillus cereus, and Bacillus thuringiensis - One Species on the Basis of Genetic Evidence. Appl Environ Microbiol 2000: 66: 2627-30.

[29] James AL, Perry JD, Jay C, Monget D, Rasburn JW, and Gould FK. Fluorogenic substrates for the detection of microbial nitroreductases. Letters in Applied Microbiology 2001: 33:403-8.

[30] Ivanova N, Sorokin A, Anderson I, Galleron N, Candelon B, Kapatral V, et al. Genome sequence of Bacillus cereus and comparative analysis with Bacillus anthracis. Nature 2003: 423: 87-91.

[31] Gwenin CD, Kalaji M, Williams PA, and Jones RM. The orientationally controlled assembly of genetically modified enzymes in an amperometric biosensor. Biosens and Bioelectron 2007: 22: $2869-75$.

[32] Gallagher S and Sasse J. Protein Analysis by SDS-PAGE and Detection by Coomassie Blue or Silver Staining: John Wiley \& Sons, Inc., 2001.

[33] Arndt C, Koristka S, Bartsch H, and Bachmann M. Native polyacrylamide gels. Methods Mol Biol 2012: 869: 49-53.

[34] Aliverti A, Curti B, and Vanoni MA. Identifying and Quantitating FAD and FMN in Simple and in Iron-Sulfur-Containing Flavoproteins. In: Methods in Molecular Biology: Flavoprotein Protocols, edited by Chapman SK and Reid GA. Totowa, NJ: Humana Press Inc. 1999. 
[35] Zenno S, Koike H, Tanokura M, and Saigo' K. Gene cloning, purification, and characterization of $\mathrm{NfsB}$, a minor oxygen-insensitive nitroreductase from Escherichia coli, similar in biochemical properties to FRase I, the major flavin reductase in Vibrio fischeri. $J$ Biochem 1996: 120: 736-44.

[36] Race PR, Lovering AL, White SA, Grove JI, Searle PF, Wrighton CW, et al. Kinetic and structural characterisation of Escherichia coli nitroreductase mutants showing improved efficacy for the prodrug substrate CB1954. Journal of Molecular Biology 2007 368: 481-92.

[37] Mossman T. Rapid colorimetric assay for cellular growth and survival: Application to proliferation and cytotoxicity assays. J Immunol Methods 1983: 65: 55-63.

[38] The recombinant protein handbook: Protein amplification and simple purification: Amersham Biosciences, 2001.

[39] Spain J. Biodegradation of nitroaromatic compounds. Annual Reviews of Microbiology 1995: 49: $523-55$

[40] Cornish-Bowden A. A Simple Graphical Method for Determining the Inhibition Constants of Mixed, Uncompetitive and Non-Competitive Inhibitors. Biochem J 1974: 137: 143-4.

[41] Kakkar T, Boxenbaum H, and Mayersohn M. Estimation of Ki in a competitive enzymeinhibition model: Comparisons among three methods of data analysis. Drug Metab Dispos 1999: 27: 756-62.

[42] Copeland RA. Enzymes: A Practical Introduction to Structure, Mechanism, and Data Analysis.: Wiley-VCH, Inc., 2000.

[43] Frey PA and Ables RH. Enzymatic reaction mechanisms: Oxford University Press, USA, 2006.

[44] Mark P Mattson, Hormesis defined, Ageing Research Reviews, 2008:7: 1-7.

[45] Parkinson GN, Skelly JV, and Neidle S. Crystal structure of FMN-dependent nitroreductase from Escherichia coli B: A prodrug-activating enzyme. J Med Chem 2000: 43: 3624-31. 
[46] Parkinson GN, Skelly JV, and Neidle S. Crystal structure of FMN-dependent nitroreductase from Escherichia coli B: A prodrug-activating enzyme. J Med Chem 2000: 43: 3624-31.

[47] Cornish-Bowden A. Fundamentals of Enzyme Kinetics. London, UK: Portland Press, 1995.

[48] Tu S-C, Becvar JE, and Hastings JW. Kinetic studies on the mechanism of bacterial NAD(P)H:flavin oxidoreductase. Arch Biochem Biophys 1979: 193: 110-6.

[49] Roldan MD, Perez-Reinado E, Castillo F, and Moreno-Vivian C. Reduction of polynitroaromatic compounds: the bacterial nitroreductases. FEMS Microbiol Rev 2008: 32: 474-500.

[50] Race PR, Lovering AL, White SA, Grove JI, Searle PF, Wrighton CW, and Hyde E. Kinetic and structural characterisation of Escherichia coli nitroreductase mutants showing improved efficacy for the prodrug substrate CB1954. J Mol Biol 2007: 368: 481-92.

[51]Helsby NA, Wheeler SJ, Pruijn FB, Palmer BD, Yang S, Denny WA, et al. Effect of Nitroreduction on the Alkylating Reactivity and Cytotoxicity of the 2,4-Dinitrobenzamide-5aziridine CB 1954 and the Corresponding Nitrogen Mustard SN 23862: Distinct Mechanisms of Bioreductive Activation. Chem Res Toxicol 2003: 16: 469-78.

[52] Helsby NA, Ferry DM, Patterson AV, Pullen SM, and Wilson WR. 2-Amino metabolites are key mediators of CB 1954 and SN 23862 bystander effects in nitroreductase GDEPT. Brit $J$ Cancer 2004: 90: 1084-92.

Figure 1: Showing a denaturing PAGE (Top) and non-denaturing PAGE (Bottom) of BC_3024 fractions after metal ion affinity separation. Top, Lane 1( EZ-Run prestained protein ladder), Lane 2 (supernatant), Lane 3 (flow through), Lane 4 (10 mM Imidazole), Lane 5 (50 mM Imidazole), Lane 6 (100 mM Imidazole), Lane 7 (200 mM Imidazole), Lane 8 (300 mM Imidazole), Lane 9 (500 mM 
Imidazole), Lane 10 (protein ladder). Bottom, Lane 1( EZ-Run prestained protein ladder), pure BC_3024 in lane 7.

Figure 2: Showing a denaturing PAGE (Top) and non-denaturing PAGE (Bottom) of BC_1619 fractions after metal ion affinity separation. Top, Lane 1( EZ-Run prestained protein ladder), Lane 2 (supernatant), Lane 3 (flow through), Lane 4 (10 mM Imidazole), Lane 5 (50 mM Imidazole), Lane 6 (100 mM Imidazole), Lane 7 (200 mM Imidazole), Lane 8 (300 mM Imidazole), Lane 9 (500 mM Imidazole), Lane 10 (protein ladder). Bottom, Lane 1( EZ-Run prestained protein ladder), Lanes 3-6 purified BC_1619.

Figure 3: TLC analysis of denatured proteins BC_1619, BC_1952, and BC_3024 as visualised under UV and compared with the migration of FMN and FAD standards.

Table 2: Kinetic parameters of NfnB_Ec, BC_3024, and BC_1619 together with CB1954, NAD(P)H, and FMN

Figure 4: A) HPLC chromatogram of a reaction mixture in the absence of NfnB_Ec, and (B) presence of NfnB_Ec enzyme. Using absorbance at $420 \mathrm{~nm}$, NADH and phosphate buffer was detected at 2- 3.5 min and the unreacted CB1954 prodrug at 11.5- $15 \mathrm{~min}$ in all chromatograms. In the presence of BC_3024, both the 4'-hydroxylamine and 2'-hydroxylamine products were detected at around 5 min and $10 \mathrm{~min}$ respectively. The products, which eluted after $15 \mathrm{~min}$, were assumed to be the 4 '-amino and 2'-amino derivatives due to lower polarity compared to the hydroxylamines. Using the area under the curves $(\mathrm{mAU} * \mathrm{~min})$ the amount of product produced was calculated and gave a ratio of $14: 86\left(4^{\prime}: 2^{\prime}-\right.$ hydroxylamine).

Figure 5: A) HPLC chromatogram of a reaction mixture in the absence of BC_3024, and (B) presence of BC_3024 enzyme. Using absorbance at $420 \mathrm{~nm}, \mathrm{NADH}$ and phosphate buffer was detected at 2- 3.5 
min and the unreacted CB1954 prodrug at 11.5-15 min in all chromatograms. In the presence of BC_3024, both the 4'-hydroxylamine and 2'-hydroxylamine products were detected at around 5 min and $10 \mathrm{~min}$ respectively. The products, which eluted after $15 \mathrm{~min}$, were assumed to be the 4 '-amino and 2'-amino derivatives due to lower polarity compared to the hydroxylamines. Using the area under the curves $(\mathrm{mAU} * \mathrm{~min})$ the amount of product produced was calculated and gave a ratio of $14: 86$ (4':2'hydroxylamine).

Figure 6: A) HPLC chromatogram of a reaction mixture in the absence of BC_1619, and (B) presence of BC_1619 enzyme. Using absorbance at $420 \mathrm{~nm}, \mathrm{NADPH}$ and phosphate buffer was detected at 2$3.5 \mathrm{~min}$ and the unreacted CB1954 prodrug at 11.5- $15 \mathrm{~min}$ in all chromatograms. In the presence of BC_1619, both the 4'-hydroxylamine and 2'-hydroxylamine products were detected at around 5 min and 10-11.5 min respectively. The products, which eluted after $15 \mathrm{~min}$, were assumed to be the 4'amino and 2'-amino derivatives due to lower polarity compared to the hydroxylamines. Using the area under the curves (mAU*min) the amount of product was calculated and gave a ratio of $67: 33$ (4':2'hydroxylamine).

Figure 7: Dixon plot for BC_3024. The concentration of inhibitor (Dicoumarol) is plotted against the inverse rate of product formation in the presence of different concentrations of NADH. All data points are the average of three repeats and trendlines are linear best fit. All trendlines are roughly parallel suggesting that inhibition by Dicoumarol is uncompetitive for this enzyme.

Table 3: Kinetics constants for $B C \_3024$ and $B C \_1619$ in presence and absence of different Dicoumarol concentrations 
Figure 8: Dixon plot for $\mathrm{BC}_{-}$1619. The concentration of inhibitor is plotted against the inverse rate of prodrug reduction in the presence of different concentrations of NADPH. Each data point represents the average of three repeats and best fit linear lines. The converging lines around the origin suggests that the inhibitor is competitively inhibiting NADPH binding to the enzyme.

Figure 9: Double-reciprocal plots of initial velocities obtained at various concentrations of CB1954, and varying concentrations of $\mathrm{NAD}(\mathrm{P}) \mathrm{H}$. A and C) BC_3024 and BC_1619 respectively produced roughly parallel lines when plotting 1/v vs 1/NADH at varying CB1954 concentrations. B and D) BC_3024 and BC_1619 respectively produced roughly parallel lines when plotting 1/v vs 1/CB1954 at varying $\mathrm{NAD}(\mathrm{P}) \mathrm{H}$ concentrations. Taken together, these results suggested that these enzymes operate with a ping-pong mechanism. All data was the result of three repeats and trendlines represented linear best fit.

Figure 10: Percentage cell survival of SK-OV-3 cells after a $4 \mathrm{~h}$ incubation with culture medium only, enzyme only, prodrug only, and increasing concentrations of BC_3024 (25 nM to $200 \mathrm{nM})$ either in presence or absence of NADH $(200 \mu \mathrm{M})$. All data points represent at least 3 repeats and error bars indicate the standard deviation.

Figure 11: Percentage cell survival of SK-OV-3 cells after a $4 \mathrm{~h}$ incubation with buffer only, enzyme only, prodrug only, and increasing concentrations of BC_1619 (25 nM to $200 \mathrm{nM})$ either in presence or absence of NADPH $(200 \mu \mathrm{M})$. All data points represent at least 3 repeats and error bars indicate the standard deviation.

Figure 12: Phylogenetic tree generated after a multiple alignment of nitroreductases (ClustalW2) to determine the relatedness of BC_1619 and BC_3024 to some common nitroreductases (NTR) and NTR-families. The results show that BC_1619 and BC_3024 fall within the oxygen-insensitive nitroreductase family. 
Table 1 Primers used for cloning of novel proteins.

\begin{tabular}{|l|l|l|l|}
\hline Gene & $\begin{array}{l}\text { Primer } \\
\text { sequence in 5' } \\
\text { to 3' direction }\end{array}$ & & $\mathrm{RE}$ \\
\hline BC_3024 & Forward & ATAGGATCCATGACTAACTCAGTAAAGAC & BamHI \\
\hline BC_3024 & Reverse & ATCAAGCTTTTATTTCCATTCAGCAAC & HindIII \\
\hline BC_1619 & Forward & ATAGGATCCATGACTAACTCAGTAAAGAC & BamHI \\
\hline BC_1619 & Reverse & ATCAAGCTTTTATTTCCATTCAGCAAC & HindIII \\
\hline BC_1952 & Forward & ATAGGATCCATGATGGCAAAGGATTTCTACTCC & BamHI \\
\hline BC_1952 & Reverse & ATAAAGCTTCGATGGTGAACAGGTTATATTCC & HindIII \\
\hline
\end{tabular}

Underlined sections indicate the location and sequence of the restriction enzyme (RE) used.

Table 2 Kinetic parameters of novel enzymes with CB1954, NAD(P)H, and FMN.

\begin{tabular}{|l|l|l|l|l|l|l|}
\hline Enzyme & Variable & Constant & Vmax & Km & Kcat & Kcat/Km \\
\hline BC_3024 & CB1954 & NADH & 8.32 & 2683.63 & 44.98 & 16760 \\
\hline & CB1954 & NADPH & 5.36 & 1642.06 & 28.95 & 17630 \\
\hline & NADH & FMN & N/A & N/A & N/A & N/A \\
\hline BC_1619 & CB1954 & NADPH & 9.76 & 2848.55 & 62.17 & 21820 \\
\hline & CB1954 & NADH & 2.97 & 868.29 & 18.91 & 21780 \\
\hline & NADPH & FMN & 0.24 & 204.75 & 1.49 & 7300 \\
\hline
\end{tabular}


Table 3 Kinetics constants for BC_3024 and BC_1619 in presence and absence of different Dicoumarol concentrations.

\begin{tabular}{|l|l|l|l|l|l|l|}
\hline Enzyme & Variable & Constant & Dicoumarol & Vmax & Km & $\alpha K_{i} / K_{i} \boldsymbol{\mu M}$ \\
\hline BC_3024 & NADH & CB1954 & $0 \mu \mathrm{M}$ & 15.19 & 7595 & NA \\
\hline BC_3024 & NADH & CB1954 & $5-40 \mu \mathrm{M}$ & 8 & 4732 & 41.6 \\
\hline BC_1619 & NADH & CB1954 & $0 \mu \mathrm{M}$ & 4.968 & 737 & NA \\
\hline BC_1619 & NADH & CB1954 & $5-40 \mu \mathrm{M}$ & 4.968 & 751 & 2095 \\
\hline
\end{tabular}


Denaturing PAGE

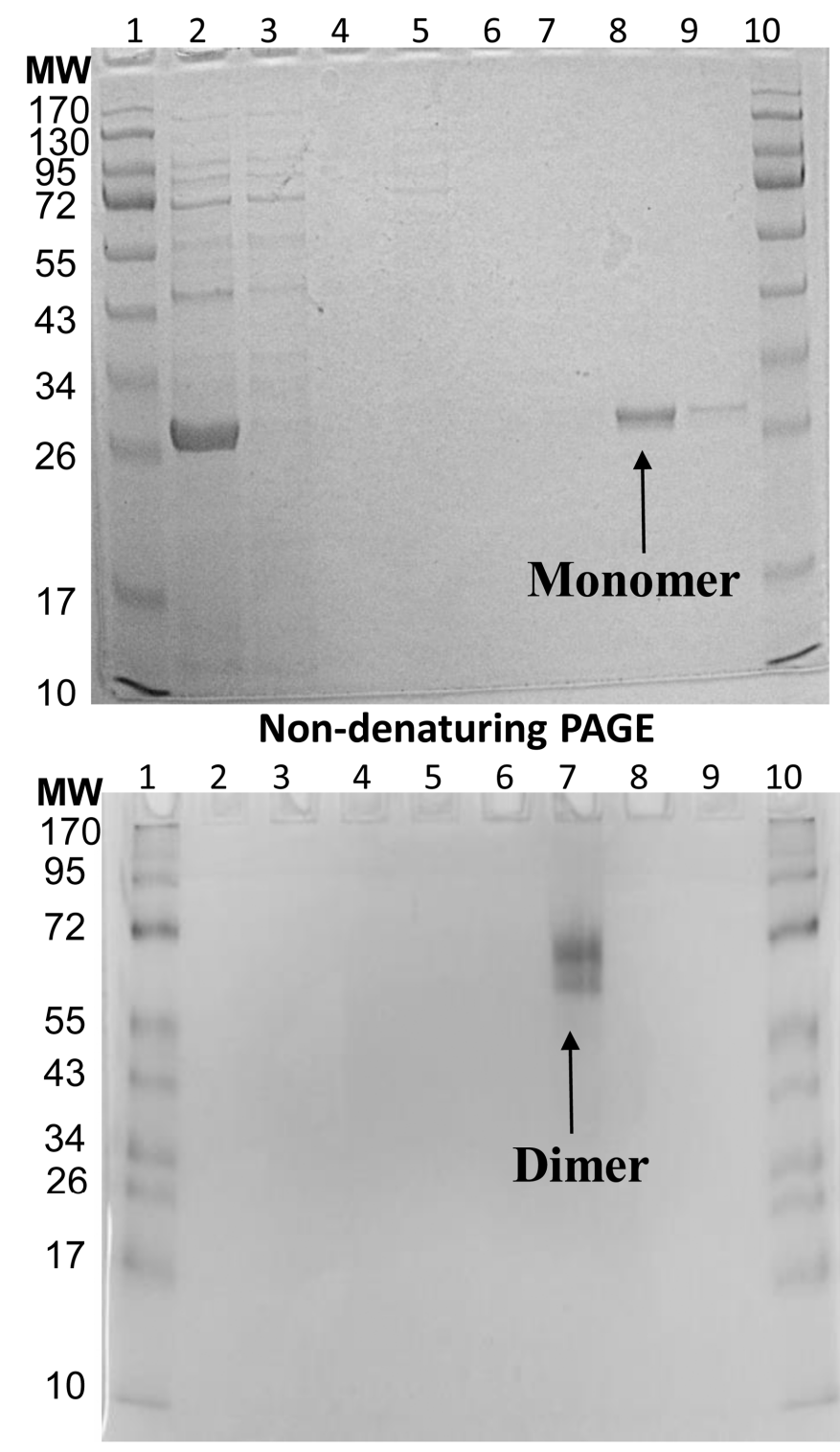

Fig 1 


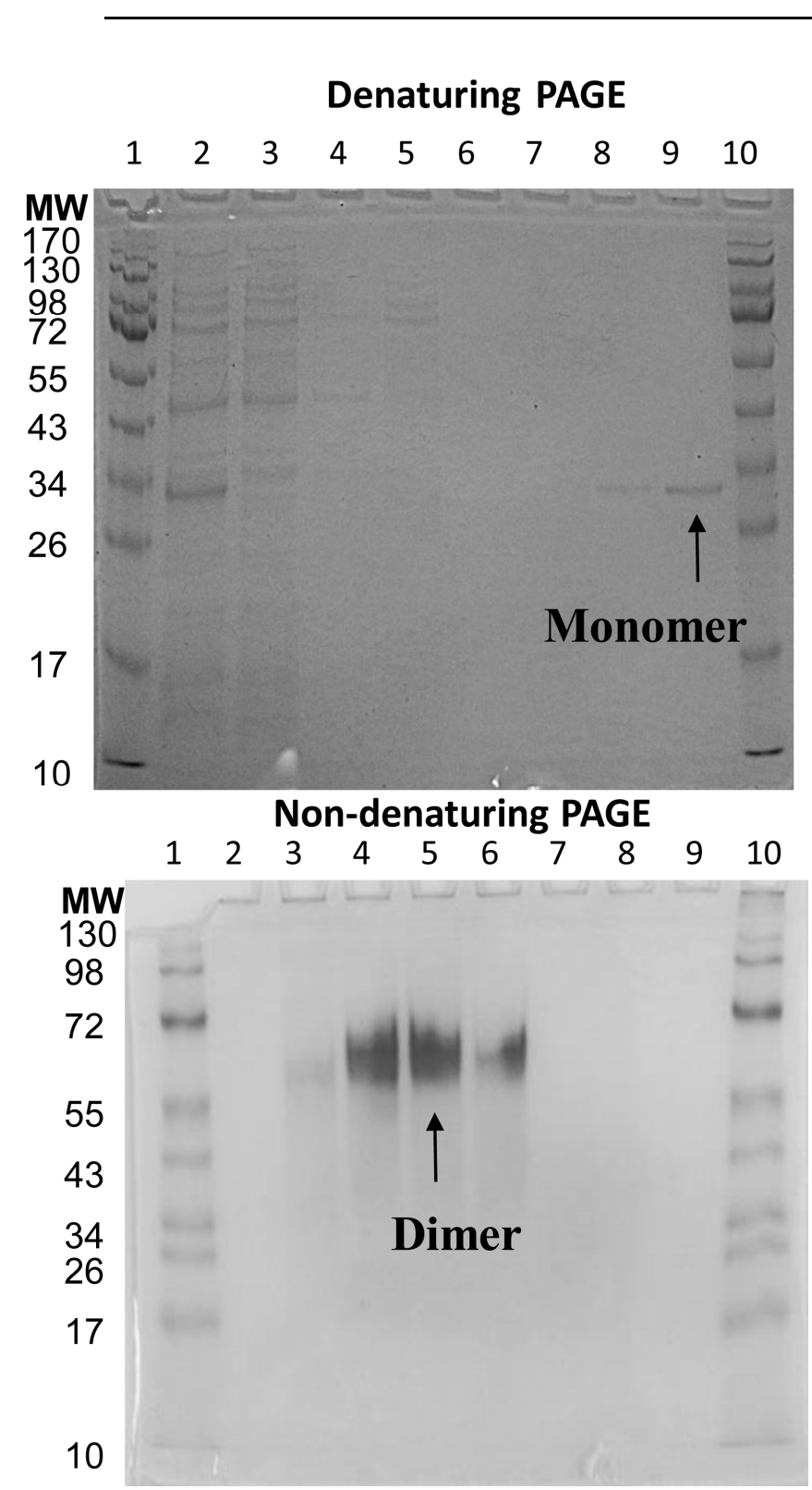

Fig 2 


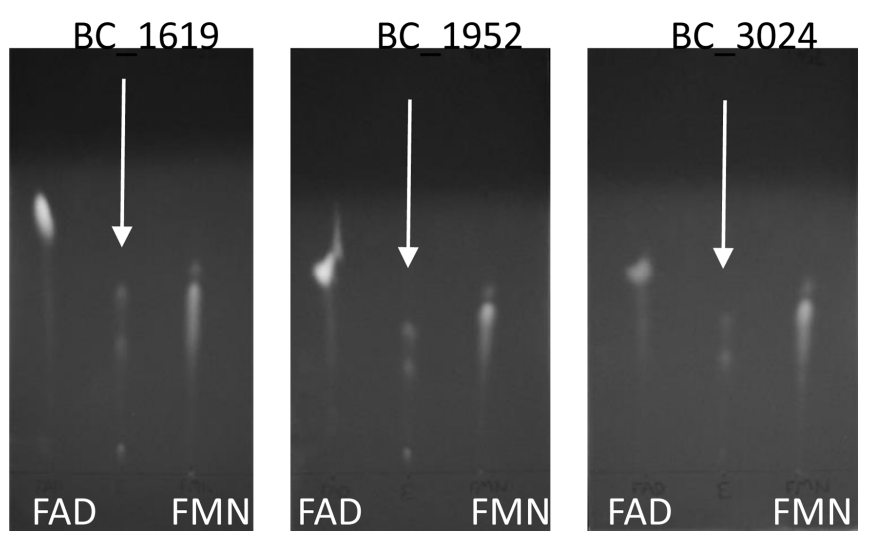

Fig 3
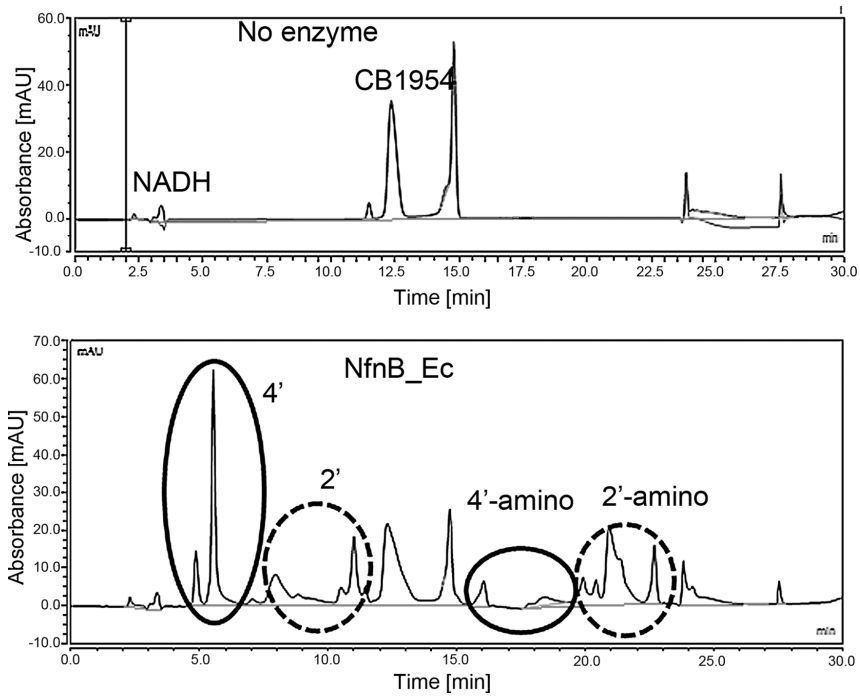

Fig 4 

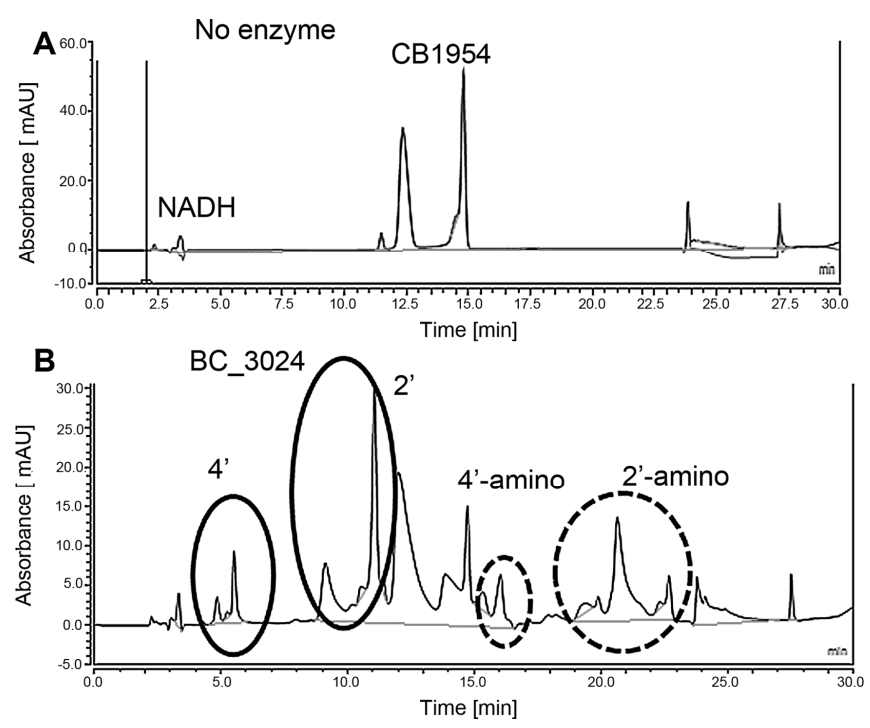

Fig 5
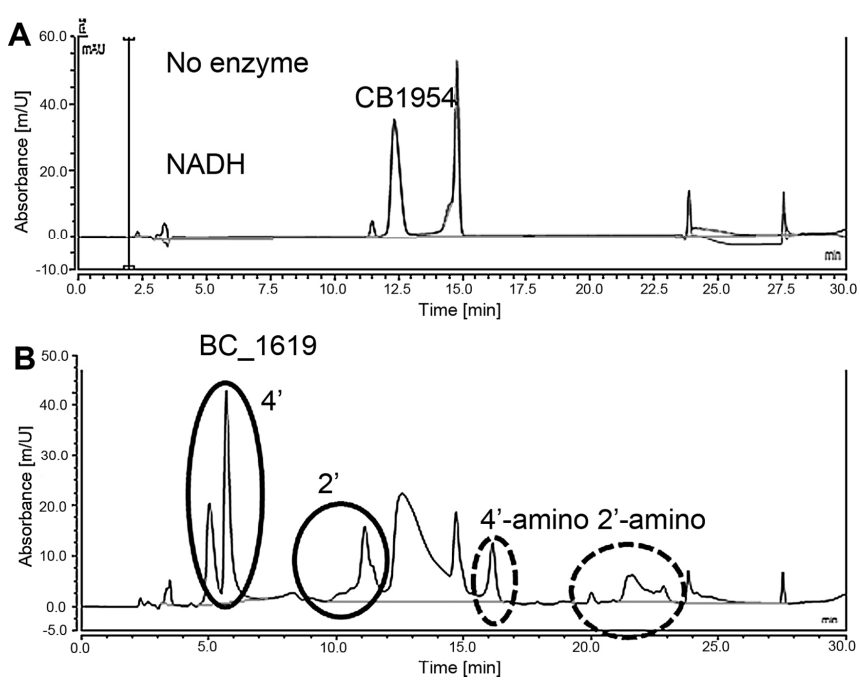

Fig 6

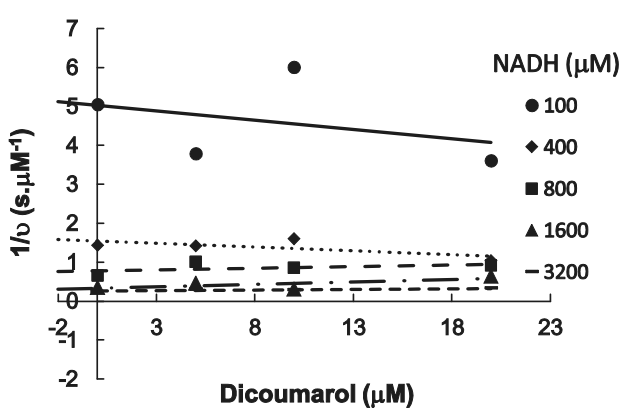


Fig 7

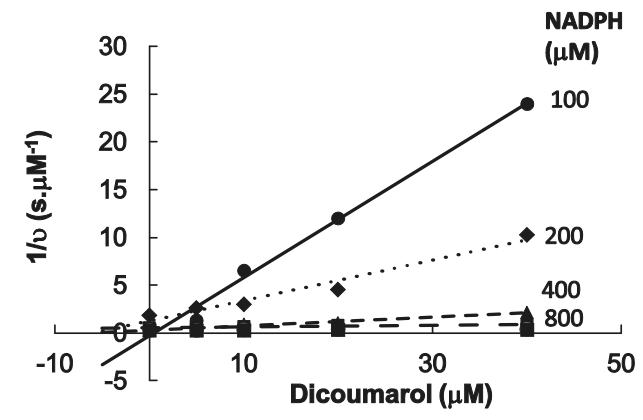

Fig 8
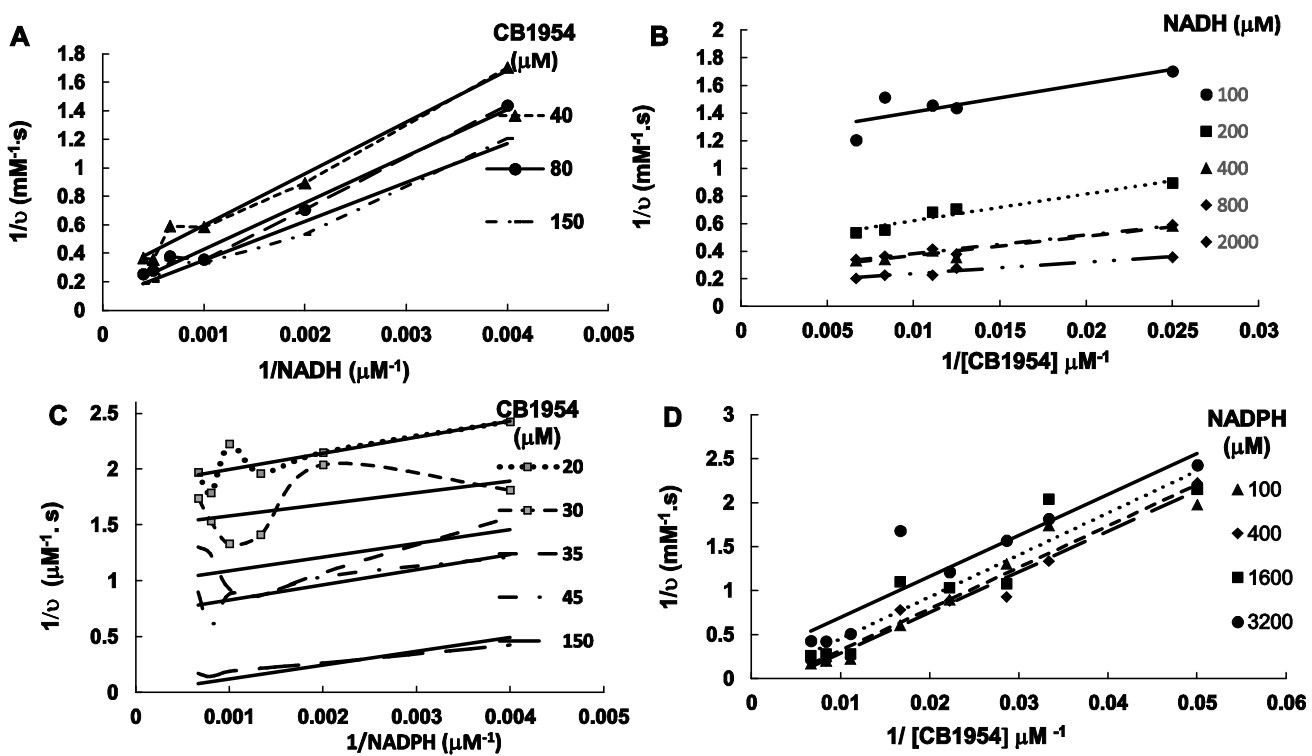

Fig 9 


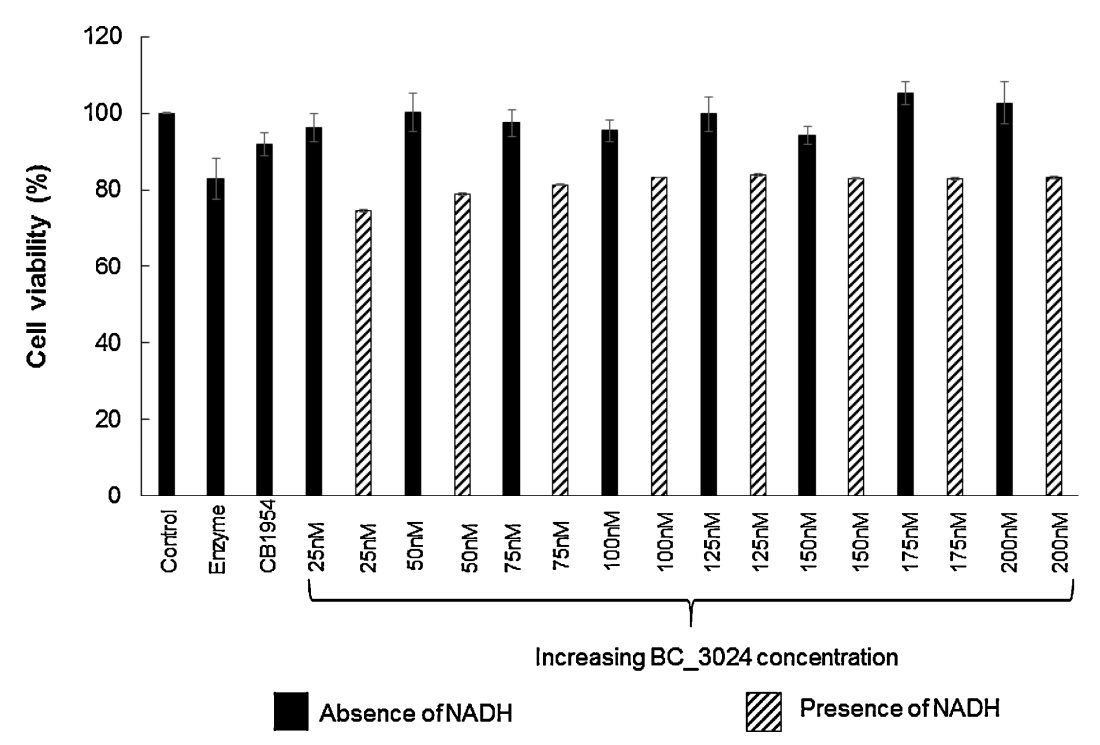

Fig 10

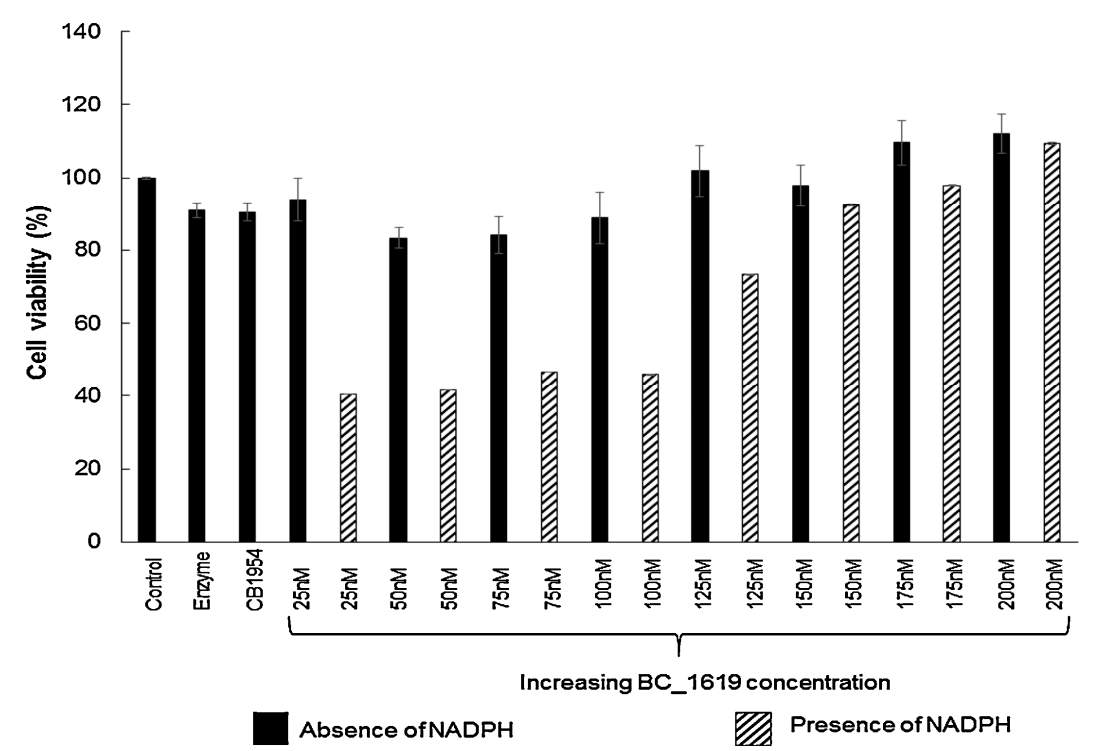

Fig 11 


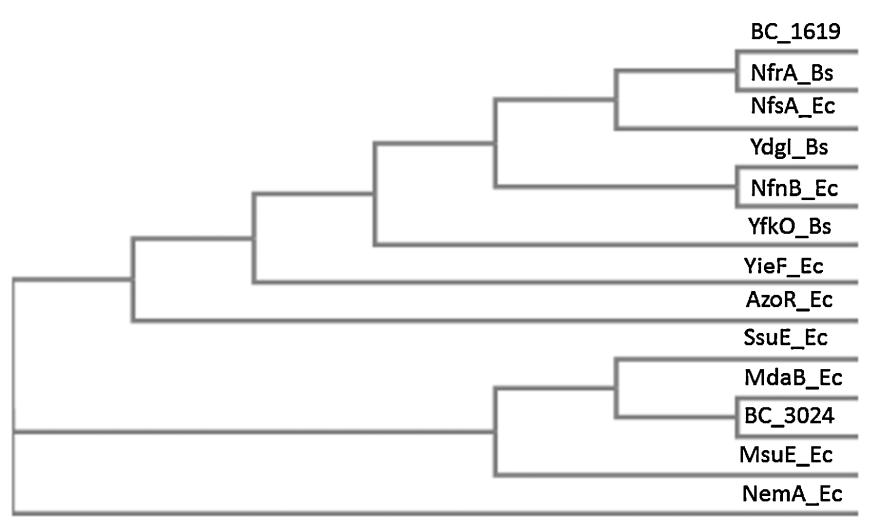

Fig 12 